Jelena Kozmina*

\title{
Osobowość i tradycja. O Natanie Tamarczence
}

DOI: http://dx.doi.org/10.12775/LC.2018.054

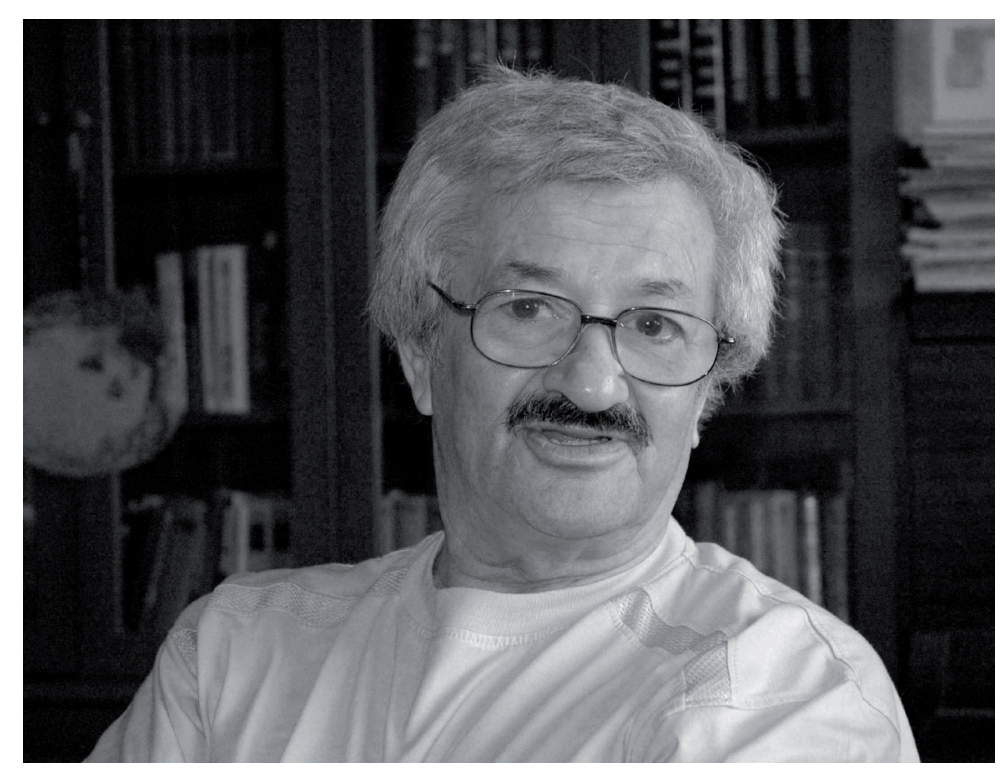

Prof. Natan Tamarczenko

Fot. Rasim M. Nazipow (źródło: archiwum prywatne)

istoria nauki o literaturze (jak zresztą każdej innej nauki) - to historia wybitnych osobowości, wielkich uczonych, ale jednocześnie - historia idei naukowych, ich ciągłości i rozwoju.

* Dr hab., profesor Uralskiego Uniwersytetu Federalnego w Jekaterynburgu, uczennica prof. Natana Tamarczenki. Jej zainteresowania naukowe obejmują poetykę teoretyczną i historyczną, teorię i historię gatunków literackich, dziedzictwo Michaiła Bachtina. E-mail: elkozmina@yandex.ru. 
Natan Dawidowicz Tamarczenko (17 lipca 1940 - 5 listopada 2011), jeden z najświatlejszych literaturoznawców XX wieku, uważał się za kontynuatora myśli Michaiła Bachtina, chociaż formalnie nie był jego uczniem, a nadto uczeni nigdy osobiście się nie spotkali. Tym niemniej Bachtin znał prace Tamarczenki. Pisze o tym we wspomnieniach żona Natana Dawidowicza - Dina Magomiedowa (2012: 13).

Stosunek literaturoznawcy do prac Bachtina nie miał nic wspólnego z modą; Natan Tamarczenko zajmował się nimi jeszcze w czasach, gdy było to przez „wysokie literaturoznawstwo" oceniane negatywnie. W jednym ze swoich tekstów Tamarczenko wspomina, że w latach siedemdziesiątych tom zbiorowy badaczy literatury z Kemerowa otrzymał negatywną opinię moskiewskiego recenzenta tylko dlatego, że cytowano tam Bachtina, co, w opinii autora recenzji, świadczyło o „prowincjonalizmie badaczy” (w tym czasie Bachtin mieszkał w Sarańsku). Do czasu wejścia książek Bachtina w obieg naukowy Natan Tamarczenko zdążył teoretycznie uściślić i rozwinąć wiele występujących w nich twierdzeń.

Co istotne - aktywnie rozwijając idee Bachtina, Natan Dawidowicz nie skrył się w cieniu wielkiego uczonego, ale pozostał niezależną postacią w rosyjskim literaturoznawstwie, twórcą głębokich koncepcji teoretycznych, jednym z założycieli „kemerowskiej szkoły poetyki teoretycznej" (Tamarczenko wykładał na uniwersytecie w syberyjskim mieście Kemerowo od połowy lat sześćdziesiątych do 1987 roku i kilka lat kierował tamtejszą katedrą literatury rosyjskiej i powszechnej); utworzył katedrę poetyki teoretycznej i historycznej na Rosyjskim Państwowym Uniwersytecie Humanistycznym (RGGU) w Moskwie.

Interpretacji twórczości Bachtina w szerokim kontekście filozoficznym poświęcona jest ostatnia książka Natana Tamarczenki, opublikowana tuż przed śmiercią autora. Idee Bachtina analizowane są tu w odniesieniu do prac takich rosyjskich uczonych, jak Aleksandr Wiesiołowski, Aleksandr Potiebnia, Aleksandr Skaftymow, Władimir Sołowjow, Wasilij Rozanow, Dymitr Mierieżkowski, Wiaczesław Iwanow, Jewgienij Trubieckoj, Andriej Bieły, Paweł Florenski.

Systematyzacji i rozwijaniu idei Bachtina poświęcone były także inne prace Tamarczenki - zarówno kolejne publikacje w ramach projektu „Tezaurus bachtinowski”, jak i monografia „Estetyka twórczości słownej” Bachtina i rosyjska filozofia religijna (2001) oraz szereg artykułów opublikowanych w zagranicznych i rosyjskich czasopismach.

W badaniach naukowych Natana Tamarczenki ważne miejsce zajmuje teoria groteski, odmienna od ogólnie przyjętej (przynajmniej w literaturoznawstwie rosyjskim). Zwykło się uważać, że obraz groteskowy powstaje w wyniku deformacji „normalnego” obrazu, że łączy przeciwieństwa, godzi rzeczy nie do pogodzenia, wyolbrzymia bądź pomniejsza przedmiot albo w ogóle przedstawia coś, co nigdy nie istniało, tzn. pokazuje odchylenie od normy. Natan Tamarczenko wychodzi od koncepcji Bachtina, wyłożonej w słynnej książce Twórczość Franciszka Rabelais'go a kultura ludowa średniowiecza i renesansu. Jednym z najważniejszych ustaleń tej pracy jest stwierdzenie obecności w historii światowej kultury nie jednej, ale dwóch norm, równoprawnych i wzajemnie się dopełniających. „Naturalne” normy leżą u podstaw „klasycznego kanonu estetycznego”, te drugie - „kanonu groteskowo-fantastycznego". Tym samym obraz groteskowy nie stanowi naruszenia normy, jej deformacji, ale jest obrazem zbudowanym według innych, nieklasycznych zasad. Dlatego Bachtin podkreślał, że nie należy interpretować obrazu groteskowego z punktu widzenia norm kanonu klasycznego; „kanon groteskowy trzeba mierzyć jego własną miarą” (Bachtin 2010: 40). 
W jednym z rozdziałów książki Bachtin mówi o „groteskowym obrazie ciała”, odróżniającym się od „gotowych”, „nieruchomych”, zakończonych, „dojrzałych obrazów ciała ludzkiego" (ibid.: 35). Wyrazistym przykładem groteskowego ciała są obrazy brzemiennych staruch, brzemiennej śmierci, w których „nie ma niczego skończonego, stabilno-spokojnego” (ibid.: 36). To obrazy ambiwalentne i pełne sprzeczności, nieoddzielone od świata; ogromne znaczenie $\mathrm{w}$ ich formowaniu ma nowy stosunek do czasu, „poczucie historii i zmiany historycznej” (ibid.: 35). Bieg czasu narusza wewnętrzne i zewnętrzne granice obrazu groteskowego, podczas gdy w obrazach kanonu klasycznego właśnie te granice są akcentowane.

Rozpatrując tak pojętą naturę groteski, Natan Tamarczenko idzie dalej; przenosi pojęcie groteski z poziomu formowania „groteskowego obrazu ciała”, tj. niezakończonego, niegotowego obrazu cielesnego, na podmiotowo-wypowiedzeniową strukturę utworu, na podmiot mowy, widzenia i oceny; i wprowadza pojęcie „podmiotu groteskowego”. „Podmiot groteskowy” (гротескный субъект) także powstaje na styku granic, ale już nie ciała, lecz świadomości (umysłu). W takim przypadku zbiorowa i indywidualna świadomość postaci albo przestają odróżniać się od siebie, albo są pokonane przez „wszechogarniającą samoświadomość” bohatera (Tamarczenko 2008a: 51). Podmiot groteskowy jest szczególnie charakterystyczny dla literatury XX-XXI wieku, gdzie może dochodzić do „zjednoczenia albo połączenia” horyzontów różnych postaci-podmiotów (czasem przechodzącego w ich fabularną transfigurację) lub wzajemnego podobieństwa postaci opartego na bezosobowości.

Zainteresowanie tym aspektem teorii groteski zaowocowało powstaniem monografii zbiorowej Dzieło literackie: problemy teorii $i$ analizy, przygotowanej przez Natana Tamarczenkę i jego uczniów (Tamarczenko et al. 2003). Z analizy „podmiotu groteskowego” badacze wywodzą pojęcie „groteskowego typu narracji”. W tych kategoriach rozpatrywane są wątki sobowtórów, które, jak sądzą autorzy monografii, korelują z podmiotem groteskowym.

Pojęcie obrazu groteskowego - i ciała, i podmiotu - Natan Tamarczenko bada w ścisłym związku ze specyfiką powieści jako gatunku literackiego, a następnie zestawia kluczowe punkty teorii groteski ze strukturą gatunkową tej odmiany powieści, która rozwijała się w obrębie tradycji karnawałowej.

Zarówno obraz groteskowy, jak i powieść wiążą się z przebiegiem czasu historycznego, ze stawaniem się. Obraz groteskowy charakteryzuje się wewnętrzną niestabilnością, jest otwarty na otaczający go świat, zmienny, „niegotowy” i dlatego jego jednoznaczne ujęcie przez podmiot przedstawiający jest niemożliwe. W powieści obserwujemy podobny związek z rzeczywistością „w sferze familiarnego kontaktu z niezakończoną współczesnością”, a także niezgodność bohatera z samym sobą, jego otwartość i niegotowość, co czyni niemożliwą ostateczną ocenę bohatera i jego świata.

Z obrazem groteskowym koresponduje także styl powieści, obejmującej różne gatunki mowy, „żywioł wielogłosowości”, opartej na przekroczeniu granic między formą literacką i rzeczywistością empiryczną. Ponadto w oczywisty sposób korespondują ze sobą Bachtinowskie pojęcia „ciało dwucielesne” (obraz groteskowy) i „słowo dwugłosowe”.

Bohater powieściowy, podobnie jak powieściowy podmiot mówiący, także charakteryzuje się niegotowością, nie jest tożsamy sam ze sobą. Stąd zainteresowanie Tamarczenki szczególnym typem bohatera - triksterem, łączącym figury oszusta, błazna i głupca (w micie trikster posiada wszystkie te cechy jednocześnie), sobowtórem „bohatera kulturowego” 
(Tamarczenko 2008b: 271-275). Związek trikstera z obrazem groteskowym przejawia się przede wszystkim w groteskowej cielesności i braku tożsamości z samym sobą.

Jedną z najważniejszych kwestii teoretycznych, nurtujących Natana Tamarczenkę w ciągu całego życia, był gatunek literacki i związane z nim pojęcia. Szczególnie interesowały go gatunki epickie (główny przedmiot jego badań to powieść), jednak podczas zajęć dla studentów i nauczycieli rozpatrywał także utwory liryczne i dramatyczne. W 2003 roku Tamarczenko opublikował dwa rozdziały w akademickiej Teorii literatury: Problem rodzaju i gatunku w poetyce Hegla (Tamarczenko 2003b: 33-63) i Problemy metodologiczne teorii rodzaju i gatunku w poetyce XX wieku (Tamarczenko 2003a: 81-98). W narodowych wariantach literaturoznawstwa pojęcia z zakresu systemu rodzajowo-gatunkowego znacząco się różnią, dlatego doniosłość takich badań jest oczywista.

Natan Tamarczenko rozpatrywał strukturę gatunkową w trzech jej aspektach - świat przedstawiony, jego stosunek do rzeczywistości pozaliterackiej (nie w sensie przeplatania się realnych i fikcyjnych zdarzeń, lecz jako granica semantyczna, wywołująca nastawienie na określoną lekturę i rozumienie utworu, określana terminem „zwieńczenie artystyczne" [завериение художественное]), struktura podmiotowo-wypowiedzeniowa. Analiza wszystkich trzech stron utworu artystycznego pozwala zrozumieć jego integralność; dlatego badania genologiczne okazują się ważne nie tyle ze względu na klasyfikację, ile dla zrozumienia sensu dzieł:

Kategoria gatunku jest niezbędna bynajmniej nie dla „klasyfikacji” - jak niestety powszechnie się sądzi (w takim wypadku jej znaczenie byłoby znikome) - ale dla adekwatnego rozumienia sensu zjawisk literackich. Przynależność utworu do określonego gatunku wskazuje na tradycyjne, historycznie trwałe i, jeśli chcemy, typowe aspekty jego znaczenia. Jednak takie rozumienie kategorii z wielu powodów okazało się niepopularne (Tamarczenko 2011: 4).

Poza tym Natan Tamarczenko poważnie i głęboko uzasadniał podział gatunków na „teoretyczne” i „konkretno-historyczne” (pisali o tym także inni badacze, ale w pracach Tamarczenki rozróżnienie to zyskało ścisłe uzasadnienie i określenie). Stworzyło to możliwość metodologicznie wyważonych badań nad typologią gatunków - opisania inwariantu gatunkowego (teoretyczna struktura, model) i wyróżnienia wariantów. Metoda ta okazała się niezwykle produktywna w badaniu konkretnych gatunków: Natan Tamarczenko opublikował szereg artykułów i monografii o klasycznej powieści rosyjskiej XIX wieku, powieści przygodowo-historycznej, o noweli rosyjskiej Srebrnego Wieku, poemacie niekanonicznym (ostatnia praca - fragment nieukończonej książki Rosyjski poemat Srebrnego Wieku Русская поэма Серебряного века).

Produktywności tej metody badań genologicznych dowodzą także prace uczniów Natana Tamarczenki, analizujących różne gatunki - metapowieść, gatunki literatury kryminalnej, fantastyki, powieść epistolarną, gotycką, historyczną, powieść-montaż, antyutopię i inne.

W ten sposób, rozwijając idee Bachtinowskie, Natan Tamarczenko stworzył własną szkołę naukową, której koncepcje kontynuowali ci, którzy uczyli się i pracowali pod jego kierunkiem w głównym nurcie poetyki teoretycznej i historycznej.

Natan Tamarczenko miał uczniów i następców w różnych miastach, a także różnych krajach (co znamienne, prawie wszyscy uczniowie Natana Dawidowicza znają się i przyjaź- 
nią). Potrafił on budować z nimi szczególne dialogowe relacje. Bardzo ważna była dlań rola „szkoły”, ścisłość metodologiczna i badawczy rygor, mimo to pozostawiał uczniom wolność (nawet naciskał na to), własne zdanie (do którego odnosił się z wielkim szacunkiem). Oto niewielki fragment z jego listu do autorki tego tekstu: „Jeśli chodzi o fantasy, to bynajmniej nie musi się Pani ze mną zgadzać. Dać impuls Pani myśli - to wszystko, do czego dążyłem”.

Nastawienie na komunikację z uczniami i współpracownikami wyrażało się nie tylko w listach i rozmowach, ale także bardziej materialnie. Tamarczenko opracował wiele tomów zbiorowych: Całość artystyczna jako przedmiot analizy typologicznej (Tamarczenko 1981), Tradycja gotycka $w$ literaturze rosyjskiej (redaktor naczelny i autor; Tamarczenko 2008c), Poetyka: słownik aktualnych terminów i pojęć (główny redaktor naukowy i autor licznych artykułów; Tamarczenko 2008d) i in.

Pedagogiczny dar Natana Tamarczenki przejawiał się w redagowaniu podręczników akademickich: dwutomowej Teorii literatury, antologii Poetyka teoretyczna: pojęcia $i$ definicje (Tamarczenko 2001), podręcznika Poetyka teoretyczna. Wprowadzenie do kursu (Tamarczenko 2006), antologii dla studentów Analiza tekstu artystycznego. Proza epicka (Tamarczenko 2005) i in. Wespół z Samsonem Brojtmanem wznowił znakomity podręcznik Borysa Tomaszewskiego z komentarzami i obszerną przedmową (Tomaszewskij 2001).

Oddzielną kartę naukowej biografii Natana Tamarczenki stanowi jego współpraca ze szkołą, opracowanie alternatywnego programu nauczania literatury i przygotowanie interesujących podręczników dla szkoły podstawowej i średniej (we współpracy z Ludmiłą Strielcową).

Jak bardzo słusznie zauważyła Dina Magomiedowa, „zadanie nauki o literaturze widział w tym, żeby znaleźć drogi do ich [tekstów - J. K.] rozumienia” (Magomedowa 2012: 12). Na tej podstawie opiera się także program kształcenia literackiego, którego cel autorzy sformułowali następująco: „uchwycenie istoty literatury artystycznej jako rodzaju sztuki i jednocześnie kształtowanie kultury percepcji czytelniczej, to znaczy zdolności do adekwatnego i głębokiego pojmowania tej istoty - sensu najróżniejszych utworów literackich” (Tamarczenko 2003c: 3).

Dialogowe „podejście rozumiejące” (понимающий подход) do utworu literackiego, i nie tylko do utworu, a w ogóle do wszystkiego, przejawiało się u Tamarczenki w umiejętności stawiania właściwych pytań, na które potem można było szukać właściwych odpowiedzi. Pytania były niezwykle ważne dla Tamarczenki, to one wyznaczały problemy, wprowadzały tekst w relacje dialogowe, przenikały wystąpienia ustne i nierzadko - pisemne. Przedmowę do znakomitej książki Rosyjska nowela Srebrnego Wieku (Problemy poetyki, fabuly i gatunku) opiera autor na domniemanej rozmowie (dialogu!) Autora i Czytelnika.

Czytelnik, wziąwszy do ręki tę książkę, zapewne pomyśli lub powie co następuje: „Proza Srebrnego Wieku - to zrozumiałe. Ale dlaczego właśnie nowela? Przecież ciekawsze, bogatsze problemowo i bardziej znane są powieści tego czasu. Oto na przykład Ognisty anioł Briusowa, Mały bies Sołoguba i Petersburg Andrieja Biełego. Być może te i inne utwory tego gatunku są ważniejsze dla rozumienia literatury epoki niż nowele tych lub innych autorów?

- Oczywiście, wymienione powieści (zwłaszcza druga i trzecia) należą do najważniejszych literackich osiągnięć epoki. Tak, nowele Briusowa, Sołoguba, a także Biełego, są rzeczywiście nie tak głębokie i nie tak doniosłe artystycznie jak ich powieści. Jednak do całej nowelistyki Srebrnego Wieku takie spojrzenie lub taka ocena nie przystaje. 
Spod pióra Natana Tamarczenki wyszły ważne prace na temat poszczególnych aspektów twórczości największych pisarzy rosyjskich - Aleksandra Puszkina, Mikołaja Gogola, Michaiła Lermontowa, Fiodora Dostojewskiego, Iwana Turgieniewa, Lwa Tołstoja, Antoniego Czechowa, Aleksandra Ostrowskiego, Borisa Pilniaka, Michaiła Berga i innych, zagranicznych - Wiktora Hugo, Jacka Londona, Maxa Frischa, Ernsta Hoffmanna, Charlesa Maturina. W słowniku bibliograficznym Pisarze rosyjscy opublikował hasła słownikowe o pisarzach „drugiego rzędu”, m.in. o Wsiewołodzie Krestowskim (autor społeczno-kryminalnej powieści Petersburskie nory). Nie jest to przypadek, wszak Natan Tamarczenko przejawiał szczególne zainteresowanie tą literaturą, którą nazywa się „masową” - kryminalną, fantastyczną.

Biografia naukowa Natana Tamarczenki okazała się zadziwiająco zwarta, mimo że przyszło mu tułać się po kraju, mieszkać i pracować w różnych miastach i republikach ówczesnego Związku Radzieckiego: Leningrad (Natan Dawidowicz urodził się w tym mieście, a po latach obronił pracę doktorską w Leningradzkim Instytucie Pedagogicznym), Kazachstan (ewakuacja w czasie II wojny światowej), Kijów (w czasie walki z „kosmopolityzmem" jego matka została zwolniona z pracy i zmuszona wyjechać z dwoma synami z miasta), Penza (tu uczył się w Instytucie Pedagogicznym), skąd następnie przeniósł się do Saratowa (i kontynuował naukę na Uniwersytecie Saratowskim). Po ukończeniu studiów Natan Tamarczenko pracował w Przewalsku (Karakole), Jełabudze, Kemerowie i, wreszcie, w Moskwie.

Natan Tamarczenko związany był nie tylko z dziedzictwem naukowym Michaiła Bachtina i innych rosyjskich uczonych, ale kontynuował także rodzinną tradycję filologiczną. Jego ojcem był literaturoznawca - Dawid Jewsiejewicz Tamarczenko (o którym Natan Dawidowicz zdążył napisać hasło do słownika bibliograficznego Rosyjscy literaturoznawcy XX wieku), matką - lingwistka i tłumaczka Róża Leonidowna Rejngand; bratem zaś - literaturoznawca Jewgienij Dawidowicz Tamarczenko. Tradycja ta nie skończyła się wraz ze śmiercią Natana Dawidowicza, przedłużają ją bowiem jego dzieci.

Tradycje naukowe żyją, odnawiając się dzięki nieprzeciętnym osobowościom twórczym, takim jak Natan Dawidowicz Tamarczenko.

Przełożyła Anna Skubaczewska-Pniewska

\section{Bibliografia}

Bachtin, Michaił Michajłowicz 2010. Tworczestwo Fransua Rable i narodnaja kultura sriedniewiekowja i Rieniessansa. W: Michaił Michajłowicz Bachtin. Sobranije soczinienij. T. 4 (2). Moskwa: Jazyki sławianskich kultur.

Magomedowa, Dina Mahmudowna 2012. „Natan Dawidowicz Tamarczenko”. Nowyj fitotogiczeskij wiestnik 2 (21): 11-16.

Tamarczenko, Natan Dawidowicz (red.) 1981. Chudożestwiennoje cetoje kak priedmiet tipołogiczeskogo analiza. Kemerowo: KemGU.

- 2001. Tieorieticzeskaja poetika: poniatija i opriedielenija. Chriestomatija. Moskwa: RGGU. 
— 2003a. „Mietodołogiczeskije problemy tieorii roda i żanra w poetikie XX wieka”. W: Tieorija litieratury. T. 3: Rody i żanry (osnownyje problemy $w$ istoriczeskom oswieszczenii). Moskwa: IMLI RAN.

— 2003b. „Problema roda i żanra w poetikie Giegiela”. W: Tieorija litieratury. T. 3: Rody i żanry (osnownyje problemy w istoriczeskom oswieszczenii). Moskwa: IMLI RAN.

- (red.) 2003c. Litieratura. 5-11 klassy. Programma dla obszczeobrazowatielnych szkot. Jekatierinburg: AMB.

- (wyb.) 2005. Analiz chudożestwiennogo tieksta. Epiczeskaja proza. Chriestomatija. Moskwa: RGGU.

- 2006. Tieorieticzeskaja poetika: wwiedienije w kurs. Moskwa: RGGU.

- 2008a. „Grotiesknyj subjekt”. W: Poetika: stowar' aktualnych tierminow i poniatij. Red. Natan Dawidowicz Tamarczenko. Moskwa: Izdatelielstwo Kulaginoj; Intrada.

— 2008b. „Trikster”. W: Poetika: stowar' aktualnych tierminow i poniatij. Red. Natan Dawidowicz Tamarczenko. Moskwa: Izdatielstwo Kułaginoj; Intrada.

- (red.) 2008c. Goticzeskaja tradicyja w litieraturie. Moskwa: RGGU.

- (red.) 2008d. Poetika: stowar' aktualnych tierminow i poniatij. Red. Natan Dawidowicz Tamarczenko. Moskwa: Izdatielstwo Kułaginoj; Intrada.

- (red.) 2011. Tieorija litieraturnych żanrow. Moskwa: Akadiemija.

Tamarczenko, Natan Dawidowicz et al. 2003. Litieraturnoje proizwiedienije: problemy tieorii i analiza. T. 2. Kemerowo: KemGU.

Tomaszewskij, Boris Wiktorowicz 2001. Tieorija litieratury. Poetika. Moskwa: Aspekt Press. 